\title{
EFFECT OF TWO FORMULATIONS OF BENZIMIDAZOLE CARBAMATES ON THE VIABILITY OF CYSTS OF ECHINOCOCCUS GRANULOSUS IN VIVO
}

\author{
DANIEL-MWUAMBETE K.* , PONCE-GORDO F.*, TORRADO J.**, TORRADO S.** \& CUESTA-BANDERA C.*
}

\section{Summary:}

Two different preparations, solution and suspension, of three benzimidazole carbamate drugs, mebendazole, albendazole and ricobendazole, were compared by analyzing their in vivo activity against Echinococcus granulosus cysts in a mouse model.

Polyvinylpyrrolidone was used for the elaboration of drug solutions and these formulations manifested better results in terms of reduction of number of viable hydatid cysts in mice than the reference drug suspensions. The effect was more prominent on mebendazole-treated mice, at doses of $25-50 \mathrm{mg} / \mathrm{kg}$. There was a correlation between $\mathrm{ED}_{50}$ and pharmacokinetical parameters of $A \cup C_{0_{-\infty}}$ and $C_{\text {max }}$ showing that a significant improvement on solubility affects the in vivo activity of these drugs.

KEY WORDS : Echinococcus granulosus, hydatid cyst, albendazole, ricobendazole, mebendazole, efficacy, solid dispersion, in vivo.
Résumé : EFfET DE DEuX FORMUlations de CARBAMATES DE BENZIMIDAZOLE SUR LA VIABILILITÉ DES KYSTES D'ECHINOCOCCUS GRANULOSUS IN VIVO

Deux préparations différentes, solution (PVP) et suspension (CMC). de trois carbamates de benzimidazole, mebendazole, albendazole et ricobendazole, ont été comparées en mesurant leur activité in vivo vis-à-vis des kystes d'Echinococcus granulosus dans un modèle murin. La polyvinylpyrrolidone a été employée pour l'élaboration des solutions de principes actifs, et ces formulations ont montré de meilleurs résultats en termes de réduction du nombre de kystes viables chez les souris que les suspensions du médicament de référence. L'effet était plus important sur les souris [PVP-mebendazole] traitées aux doses de $25-50 \mathrm{mg} / \mathrm{kg}$. II existe une corrélation entre les ED50 et les paramètres pharmacocinétiques d'AU $C_{0_{-\infty}}$ et $C_{\text {max }}$, prouvant qu'une amélioration significative de la solubilité du principe actif affecte l'activité in vivo de ces médicaments.

MOTS CLÉS : Echinococcus granulosus, kyste hydatique, albendazole, ricobendazole, mebendazole, efficacité, dispersion pleine, in vivo.

factors as drug absorption and residence time in the host body. Therefore, one way of improving the therapeutic effectiveness of bencimidazoles would be by increasing their solubility by formation of drug complexes with polyvinylpyrrolidone. If solubility is the limiting step for their oral absorption (Cotting et al., 1990) the solution formulations should provide better bioavailability than the conventional drug suspensions. Thus, the intention of the present study is to carry out comparative and analytical studies of different formulations of $\mathrm{ABZ}, \mathrm{RBZ}$ and $\mathrm{MBZ}$ in an in vivo mouse model.

\section{MATERIAL AND METHODS} Several factors may account for the differences observed in therapy reports, including host-dependent

\footnotetext{
* Departamento de Parasitología, Facultad de Farmacia, Universidad Complutense de Madrid. Plaza Ramón y Cajal s/n, 28040 Madrid, Spain.

** Departamento de Farmacia y Tecnología Farmacéutica, Facultad de Farmacia, Universidad Complutense de Madrid. Plaza Ramón y Cajal s/n, 28040 Madrid, Spain.

Correspondence: Francisco Ponce Gordo.

Tel.: +3413941817 - Fax: +34139418 15 .

E-mail: pponce@farm.ucm.es
}

$\mathrm{D}$ rugs solubilization was performed by complexation with polyvenylpirrolidone K12 PF (PVP) (Basf, USA) in the proportions of 1:20 (w:w) for MBZ (Sigma, USA) and 1:10 for both ABZ (SmithKline Beecham, England) and RBZ (Chemo Ibérica, Spain). The solvent evaporation method was used in preparation of solid complexes (Torrado et al., 1996). Drug concentrations were adjusted to $1 \mathrm{ml} /$ day doses of 5,25 and $50 \mathrm{mg}$ of drug per $\mathrm{kg}$ of body 
weight. PVP-dispersed drugs were dissolved in distilled water. The reference drugs were suspended in $1 \% \mathrm{car}-$ boxymethylcellulose (CMC).

Twenty five to forty days old female NMRI mice were infected by i.p. injection of 2,000 protoscoleces of sheep origin in $0.5 \mathrm{ml}$ of Hank's Balance Salt Solution. Eight to ten months post infection, mice were divided into 21 groups of 10 mice each: blank control, CMC control, PVP control, and a group for each of the drugformulation-dose combinations. Except for the blank control group, the preparations (CMC or PVP with/ without drugs at the appropriate concentration) were respectively administered by gavage $(0.5 \mathrm{ml}$ at 12 hours intervals; $1 \mathrm{ml} /$ day in total) during two regimes of five consecutive days with a two days break in between. Drugs effect was evaluated 30 days post-treatment. Mice were sacrificed by anaesthesia with diethyl-ether followed by cervical dislocation. The developed cysts were removed and counted; their viability was determined on the basis of their macroscopic appearance (turgency, color, hydatid fluid transparence). The $\mathrm{ED}_{50}$ for each drug-formulation-dose combination was determined by the extrapolation method from the mean percentages of viable cysts in mice.

For the drug relative bioavailability studies, the PVPdrug complexes were dissolved in deionized water and orally administered to two months old female NMRI mice by a bucco-gastric tube at a dose of $100 \mathrm{mg} / \mathrm{kg}$. The reference formulations were prepared using a $1 \%$
CMC suspension as vehicle. Blood samples were collected by exanguination of at least three mice by heart puncture at 15, 30, 45, 60, 90, 180, 360 and 540 minutes post-administration. The blood samples were individually heparinized and centrifuged. The resulting plasma samples were stored at $-20^{\circ} \mathrm{C}$ until HPLC analysis. The parameters $\mathrm{AUC}_{0-\infty}, \mathrm{T}_{\max }$ and $\mathrm{C}_{\max }$ were calculated as the mean values of time $\left(\mathrm{T}_{\max }\right)$ taken to achieve the maximum plasma concentrations $\left(\mathrm{C}_{\max }\right)$ for the mice, which is the highest drug plasma concentration reached by each administered formulation. $\mathrm{AUC}_{0-\infty}$ was calculated as the sum of $\mathrm{AUC}_{0-9}$ (determined by the trapezoidal rule method) and $\mathrm{AUC}_{9-\infty}$ (estimated as the quotient of $\mathrm{C}_{9}$ and $\mathrm{K}_{\mathrm{e}}$ ). $\mathrm{K}_{\mathrm{e}}$ was calculated as the slope from the final phase of the log concentration-time curves (Shargel \& Yu, 1993).

Differences among the means of various groups were identified by Analysis of uni-and-multivariable variances and significance level was set at $\mathrm{P}<0.05$.

\section{RESULTS}

R esults for the in vivo treatment of infected mice are shown in Figure 1. ABZ and RBZ behaved similar at the different doses and at the two formulations and they only showed a significative activity at the higher dose of $50 \mathrm{mg} / \mathrm{kg} /$ day. $\mathrm{MBZ}$ showed to be the most effective at 25 and $50 \mathrm{mg} / \mathrm{kg} /$ day for

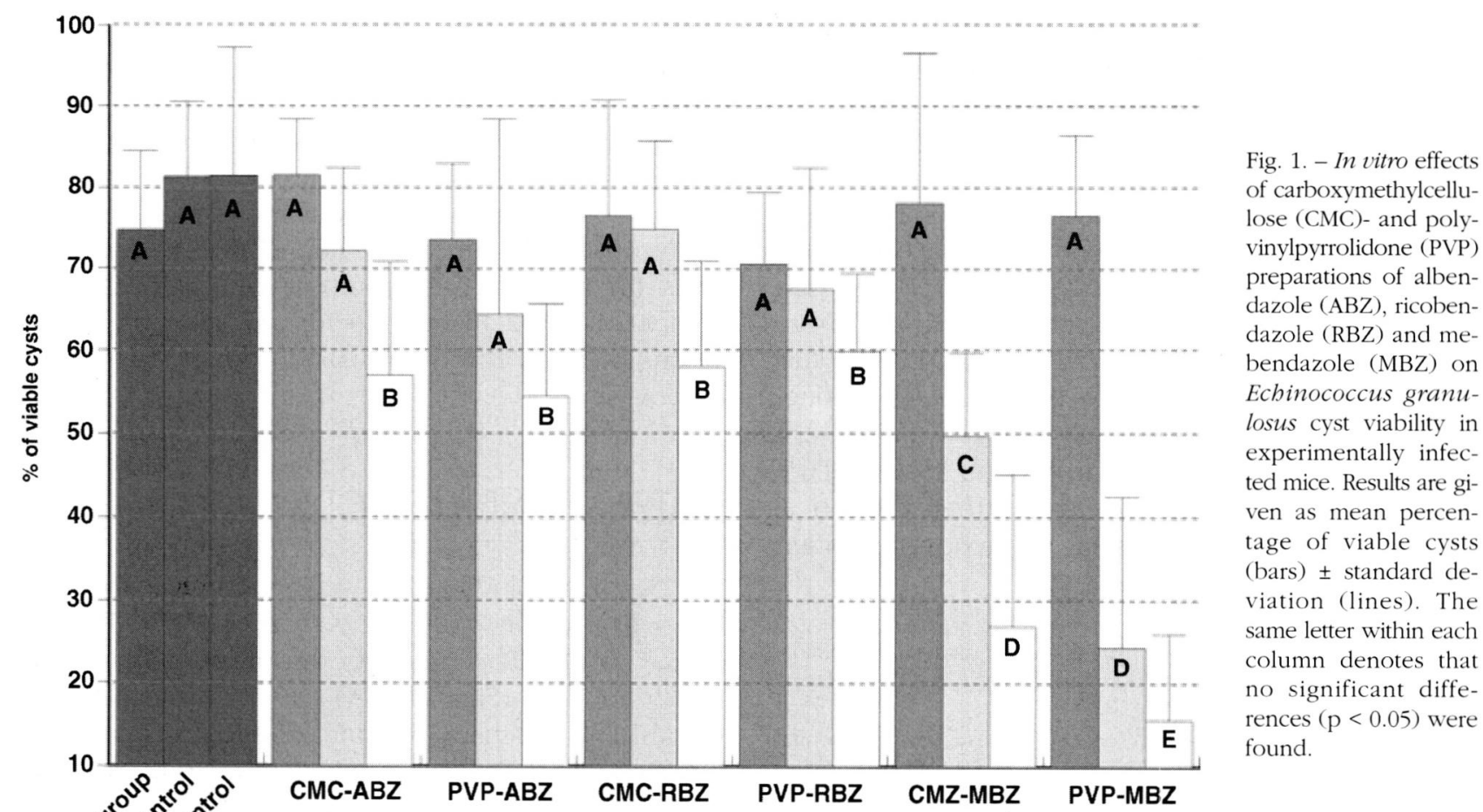




\begin{tabular}{lcccc}
\hline \multicolumn{1}{c}{ Drug preparations } & $\mathbf{E D}_{\mathbf{5 0}}$ & $\mathbf{A U C}_{\mathbf{0}-\mathbf{\infty}}$ & $\mathbf{C}_{\max }$ & $\mathbf{T}_{\max }$ \\
\hline CMC-ABZ (suspension) & 65 & 0.5 & $0.3 \pm 0.1$ & $0.4 \pm 0.4$ \\
PVP-ABZ (solution) & 56 & $0.8^{*}$ & $0.7 \pm 0.1^{*}$ & $0.3 \pm 0.1^{*}$ \\
CMC-RBZ (suspension) & 71 & 216.5 & $28.5 \pm 1.0$ & $1.3 \pm 0.3$ \\
PVP-RBZ (solution) & 79 & $188.9^{*}$ & $37.1 \pm 2.0^{*}$ & $0.3 \pm 0.1^{*}$ \\
CMC-MBZ (suspension) & 31 & 9.3 & $1.1 \pm 0.1$ & $1.1 \pm 0.4$ \\
PVP-MBZ (solution) & 24 & $25.9^{*}$ & $6.1 \pm 0.4^{*}$ & $0.8 \pm 0.3^{*}$ \\
\hline
\end{tabular}

Table I. - Correlation between in vivo pharmacokinetical parameters and drug activities $\left(\mathrm{ED}_{50}\right)$ against Echinococcus granulosus cysts in mice. The asterisk denotes that correlation is statistically significant $(\mathrm{p}<0.05)$.

both formulations, with an increased efficacy when in PVP respect to CMC at both doses.

Table I shows the correlation between drugs activities $\left(\mathrm{ED}_{50}\right)$ and physicochemical parameter results. Significant negative correlations were found between $\mathrm{ED}_{50}$ and $\mathrm{AUC}_{0-\infty}$ and $\mathrm{C}_{\max }$ and positive correlation with $\mathrm{T}_{\max }$ for the preparations of $\mathrm{ABZ}$ and $\mathrm{MBZ}$. On the other hand, from RBZ preparations a negative correlation was observed among $\mathrm{ED}_{50}$ and $\mathrm{AUC}_{0-\infty}$ and $\mathrm{T}_{\max }$, whilst a positive correlation was observed with $\mathrm{C}_{\max }$.

\section{DISCUSSION}

T The presence of the parasite in the host do not affect the pharmacokinetical parameters of bencimidazoles orally administered (García-Llamazares et al., 2001), then it should be valid to apply results obtained from healthy mice to the parasited ones. CMC and PVP have showed no anti-cyst activity, and their importance is only related to their contribution to drug absorption and thus increased bioavailabity.

The present study shows that changes in the pharmacokinetical parameters obtained with PVP formulations should increase the in vivo efficacy of the bencimizadoles against cystic E. granulosus. Although this result should be expected against tissue parasites, they were not observed by López et al. (1997) when testing the same PVP formulations of $\mathrm{ABZ}$ and $\mathrm{RBZ}$ against parenteral Trichinella spiralis encysted larvae. The data obtained show that PVP-drug formulations are specially recomended for the less soluble drugs (as MBZ), while for those more soluble (as ABZ and RBZ) the pharmacokinetical differences should be almost negligible and their anti-cyst activity should have no changes.

The anomalous pharmacokinetic results obtained by us in relation to the RBZ formulations are probably due to the small differences found between them. RBZ is the most soluble drug and so the election of a solution dosage form instead of a suspension form is less critical with regard to the pharmacokinetical characteristics than with the other less soluble drugs, MBZ and ABZ.

\section{REFERENCES}

Carpio A., Santillan F. \& Leon P. Is the course of neurocysticercosis modified by treatment with anthihelmintic agents? Archives of Internal Medicine, 1995, 155, 1982-1988.

Cotting J., Zeugin T., Steiger U. \& Reichen J. Albendazole kinetics in patients with echinococcosis: delayed absorption and impaired elimination in cholestasis. European Journal of Clinical Pharmacology, 1990, 38, 605-608.

Da Silva N., Guyatt H. \& Bundy D. Anthihelmintics-A comparative review of their clinical pharmacology. Drugs, 1997, 53, 769-788.

EL-ON J. Benzimidazole treatment of cystic echinococcosis. Acta Tropica, 2003, 85, 243-252.

García-Llamazares J.L., Merino-Peláez G., Larrode-Pellicer O., Redondo-Cardena P.A., Prieto-Fernández J.G. \& AlvarezDE-FELIPE A.I. Pharmacokinetics of netobimin and microsomal metabolism of albendazole in infected gerbils with Echinococcus gramulosus. Parasitology Research, 2001, 87, 107-111.

Lopez M.L., Torrado Susana, Torrado Santiago, Martinez A.R. \& Bolas F. Improvement of albendazole efficacy against enteral, but not against parenteral stages of Trichinella spiralis by preparing solid dispersions in polyvinylpyrrolidone. Chemotherapy, 1997, 43, 430-435.

SHARGEL L. \& YU A.B.C. Applied biopharmaceuticals and pharmacokinetics, $3^{\text {rd }}$ ed. Prentice Hall, New Jersey, 1993.

Torrado Susana, Torrado Santiago, Torrado J.J. \& CadorNIGA R. Preparation, dissolution and characterization of albendazole solid dispersions. International Journal of Pharmaceutics, 1996, 140, 247-250.

Reçu le 27 janvier 2003 Accepté le 9 septembre 2003 